\title{
ORGANIZED VIOLENCE AND ELITE POLITICAL CULTURE IN NIGERIA
}

DOI: $10.20542 / 2307-1494-2021-2-192-194$

Ebimboere S. Why Organised Violence Thrives in Nigeria: The Problem of Elite Political Culture. Cambridge: Cambridge Scholars Publishing, 2020. $235 \mathrm{p}$.

In her book "Why Organised Violence Thrives in Nigeria: The Problem of Elite Political Culture" (2020) Seiyefa Ebimboere seeks to outline the essence of how organized violent groups, in particular the "Boko Haram" sect, are generated and sustained by elite political culture. She concentrates on the role of elite political culture, and specifically the link of elite political culture to politics and governance, as the basic driver and catalyst of organized political violence. Political elite's approach to state governance in Nigeria is based upon a political culture of self-interest, which the author identifies as one of the main factors behind continuation of organized violence in the country. The book consists of seven chapters dedicated to description, dimensions and analysis of organized political violence in Nigeria.

Chapter 1 provides an insight on the content and the main idea of the book in which the author makes a correlation between persistence of organized political violence and the style of governance in Nigeria. Unlike other scholars in the field, the author does not prioritize the problems of "unemployment, poverty and corruption" (p. 2) as the core drivers of political violence, instead identifying them as "amplifiers". She believes the ambition of political elite to maximize state power and wealth and the deeply embedded practice of the use of violence to achieve political objectives shape the patterns of organized violence in Nigeria.

Chapter 2 continues to investigate various aspects of how political culture of elites and the specifics of governance are correlated with ongoing organized violence in Nigeria. The author asserts that the quality of governance suffers badly from the political elites' approach to violence as a "power-sustaining" mean to reach personal goals and a strategy for insuring political interests. This brings up the issue of the absence of accountability and of frustration among population that eventually push social movements to require better services from the government to Nigerians populace or even to replace misgovernance by the state with their own quasi-governance. These social movements, according to Ebimboere, can become organized violent groups by allying with (segments of) political elites. Overall, she argues, bad and inefficient governance is rooted in the functioning of elite political culture in the country that is based upon "zero-sum politics, identity politics, and the politicization of social cleavages" (p. 10).

Chapter 3 focuses on the evolution of the political environment in Nigeria and on how political elites sustain violence on the basis of culture and ethnicity. Here, the author provides an outline of the historical foundation of Nigeria's political development, including numerous episodes of politically driven violence that have shaped it in the postindependence era. As noted above, inadequate administration by political elites fostered a climate conducive to the creation of social movements and their evolution into organized violent groups. According to Ebimboere, the main trends that enabled this transition were "ethnic or regional marginalization, ethnic rivalry, elite patronage, and violence as an alternative method of accessing state power" (p. 67). Following that, these social movement 
groups became tools for political mobilization and advancing of political interests of the elite that quite often included the willful use of violence.

In chapter 4, the author discusses how Nigerian political elites exploit religion, particularly Islam, as a tool of influencing political sphere. To her, the phenomenon of Islamic sects allowed the political elite to adopt the sects' objectives as political propaganda materials, which helped them to gain political mobilization and legitimacy. The author finds that the government's approach to Islamic sects at the national and state levels, spurred by the perception of a threat to its power, first resulted in alliances between sects and the government and subsequently lead to intensified violence. Driving attention to the emergence of groups such as "Boko Haram" and "Yan Tasine", she insists that it is these alliances, fueled by poor state governance, that provoked the transformation of social movement groups into organized political violence groups.

Chapter 5 places the formation and transition of "Boko Haram", MEND, and the "Bakassi Boys" into organized violent groups in the broader context of Nigeria's political culture. According to Ebimboere, "Boko Haram"'s actions, strategic outlook, and objectives demonstrate that these groups grew out of political culture that "sacrifices good governance for political gain" (p. 96). She argues that, while religious in essence, "Boko Haram"'s ideology was contextualized in, and reflected, socioeconomic and political grievances, and reinterpreted the structural challenges faced by Nigerian society as a consequence of the lack of Islamic religious principles in the political domain. As a result, "Boko Haram" advocated an "Islamized Nigeria" as a remedy to these structural deficiencies (p. 104).

The penultimate chapter focuses on the failure of the Nigerian government's counterterrorism and counterinsurgency responses to organized violence carried out by "Boko Haram" and reviews the tactics employed in response to this and other insurgencies. Ebimboere divides the process of implemented tactics into four phases and claims political elite's active involvement in them, which mainly ignited further violence. She believes that as "Boko Haram"'s activities became counterproductive to elite objectives, the national authorities responded with a large military campaign, resulting in the insurgency's shift to increasingly asymmetrical guerrilla tactics against the police and the military and to extreme terrorist tactics against civilians such as synchronized suicide attacks and mass abductions.

The final chapter sums up the book's findings and concepts that include, but are not limited to, the depiction of Nigerian politics as a zero-sum game, the idea that the progress in political competition emerges from mobilizing vital social groups, and the emphasis on the political elite's self-serving culture of politicizing state conflicts. Ebimboere makes the concluding remark by stating that the demise of "Boko Haram" would not put an end to Nigeria's organized violence - rather, it would only be a momentary break until the next violent uprising emerges, if elite political culture and approaches to governance remain unchanged.

The main strength of the book is Ebimboere's thorough reflection on the issue of ongoing political violence in Nigeria. To begin with, she does not rely on any single driving factor of political violence, but discusses various drivers in depth throughout chapters: the role of political elites' approach to governance in chapter 2, the influence of ethnicity in chapter 3 , and the impact of religion and religious radicalization on organized political violence in chapter 4 . Her effort to dive deeper in analyzing the roots of the problem and conclusion that thriving organized political violence in Nigeria stems from fundamental problems, rather than resulting from one or several specific "causes". These features of the 
book distinguish Ebimboere's work from other scholarly literature in the field, which often identifies the manifested effects of political violence as its "causes".

The author makes a major effort to be as objective and unbiased as possible in her approach. While exploring the triggers behind, and preconditions for, ongoing organized political violence in Nigeria throughout the volume, she does not follow a common path of simply laying all the blame on violent groups and never keeps the elite out of discussion. This stands in contrast to works by many scholars prior to her who avoided analyzing the impact of political classes and degraded the violent groups to mere outliers in the society.

Another strong point of the book is the broad discussion of ideas and concepts developed by scholars at different times and of different professional background. Through the chapters, Ebimboere not only explains her vision on continuing political violence in Nigeria, but also refers to and reflects on the ideas of various authors in the field, giving readers an extensive insight on the subject. For instance, while deliberating on the correlation between politics and religion in chapter 4 , she thoroughly reviews the literature on the subject written by scholars from different parts of the world.

Without doubts, this book is an excellent study that discusses and analyzes thriving organized violence in Nigeria and how it correlates with the political elite culture and patterns of governance. The book, however, could have benefited from more of a comparative discussion of organized violence groups, instead of paying central attention to "Boko Haram", and from deliberations on how Nigerian political and governance cultures manifest themselves in relation to different violent non-state actors. That discussion could have strengthened her point about the correlation between the role of political elites and organized political violence.

Despite the lack of discussion and reflection on certain aspects on the topic, the volume is thoroughly informative, well researched, and intellectually rewarding. This book is a useful guide for all those who want to broaden their awareness of organized political violence in Nigeria.

Fidan Mirzayeva (Azerbaijan)

ADA University, Baku ORCID: 0000-0002-6585-247X 